\title{
Entrepreneurship Practice: As a Means of Poverty Reduction in Southwestern Nigeria
}

\section{Popoola Mufutau Akanmu}

PhD, Department of Business and Entrepreneurship, School of Business and Governance, Kwara State University, Malete, Nigeria

\section{Aminu N. Brimah}

$\mathrm{PhD}$, Department of Business and Entrepreneurship, School of Business and Governance, Kwara State University, Malete, Nigeria

\section{Rotimi Ayodele Gbadeyan}

$\mathrm{PhD}$, Department of Marketing, Faculty of Management Sciences, University of Ilorin, Nigeria

\begin{abstract}
The main purpose was to examine and analyze the strong impact of entrepreneurship practices on poverty reduction in Southwestern Nigeria. This poverty issue has become households name in Nigeria, and despite various economic development polices and many different strategic policies designed to reduce poverty through human and highly capital development. Also, most economist guru in Nigeria has forecasted that, if government can make proper use of an entrepreneurship practices in all business sectors of their economy, poverty will be a thing of the past in Nigeria. These set of people view entrepreneurship practices as a business, which will involve suitable set of people who are fully ready to take risks in all their business activities. Ready prepared to identify every business opportunity and obtain materials, plan, and implement workable action that will achieve the business expectation. Data collection was done by interview, in-depth discussion with respondent. The study of this nature require highly proper interview in order to get desire results. Field note, and documentation are also used to complement the interview in order to get desired result. Pure and table water industry business owners are only key respondent in this study. Descriptive Statistics and Partial Least Square (PLS) analysis are method of data used. The reason why researcher is using this method is that it will easily show if entrepreneurship practices can solve poverty issue or not. The finding revealed that entrepreneurship practices have highly positive impact on poverty reduction in Southwestern Nigeria. Enterprise business operators are prospering well, but still need optimized entrepreneurial competency in all their activities to achieve the desired result. The result strongly indicates that in Nigeria, the Entrepreneurship practices are most antidote to poverty reduction and job creation at this moment that Nigeria is technically moving out of the economic recession.
\end{abstract}

Keywords: entrepreneurship, means, poverty, practice and reduction.

JEL Classification: L26, I32.

Cite as: Popoola, M. A., Brimah, A. N., Gbadeyan, R. A. (2018). Entrepreneurship Practice: As a Means of Poverty Reduction in Southwestern Nigeria. Business Ethics and Leadership, 2(4), 83-88. http://doi.org/10.21272/bel.2(4).83-88.2018.

(C) The Authors, 2018. This article is published with open access at Sumy State University.

\section{Introduction}

\subsection{Background of the Study}

Poverty in Nigeria this day is skyrocketed. Omoh (2012) quoting the poverty data released by National Bureau of Statistics revealed that 112 million Nigeria representing 70 percent live below one dollar a day and British Broadcasting Corporation (BBC) 2012 agreed with this when it quoted poverty data at 112.47 million; stating that absolute poverty can be measured by those who can afford only the bare essentials.

Omoh is of the view that Nigeria appears to be in a poverty trap: a vicious circle that takes hard work and massive investment to break. According to Omoh, the population is rising faster than the economy can cater for, which is breeding poverty in Nigeria.

Poverty in any community is a serious setback to the economic, political, social and general development of the society. More so, in a society like this characterized by low educational level, unskilled labor, wasteful 
lifestyle, non-delivery of total quality policy package based on needs, policy leakages to non-target population and traditional values and norms have all affected the performance of poverty alleviation initiatives. Emanating from the above, one can conclude that economic of Nigeria and most of developing countries are largely characterized and defined by the rate of poverty, hunger and employment subsisting in them.

It seems as if all strategies applied in the past to fight poverty proved ineffective, but the world seems to have found a most promising strategy through Entrepreneurship Practices. Entrepreneurship refers to an individual ability to turn ideas into action. Entrepreneurship is the process of designing, launching and running a new business, while the person who creates this business is called an entrepreneur. Despite the significant academic attention paid to the concepts of entrepreneur and entrepreneurship, consensus has yet to be achieved with respect to single definition that are concise and that present entrepreneurship as a field of study.

Ogundele (2017) defines entrepreneur as the innovating individual, who initiates and nurtures to growth a new and an ongoing business organization, where none has existed before. He explain further that, he is the individual, who initiates actions to commence it, and manages it through its initial problems and struggles for survival. He takes all measures that lead the organization to a point of good stability and self-sustaining growth. In fact, a person is an entrepreneur when he/she performs the above-described functions. Of an empire builder. Also, entrepreneur is a catalyst for economic change, who uses purposeful searching, careful planning and sound judgement when carrying out the entrepreneurial process. The entrepreneur works creatively to set up new resources or endow old ones with a new capacity, all for the purpose of creating wealth. The above definition were merely an attempt at describing some of the aspects of entrepreneurs' behavior and functions. It is also based on the perception and merely academic research of the authors.

Entrepreneurship is usually used to indicate function or activity. It may be occasionally used to signify the commonality of entrepreneurs. With this effect, the aggregate of individuals performing entrepreneurial activities or carrying on that function in a given time, place, or even over considerable period of time. In this respect, entrepreneurship can be used in reference to certain classes of society.

The word entrepreneurship have been used differently. That distinction have been made or glossed over among invention, creativity and innovation, imitation and risk-taking in economic literature.

\subsection{Statement of Research Problem}

Poverty is sometimes superimposed on man by nature and the predicament man find himself in. With indices of economic recession, unemployment, galloping inflation, dilapidated infrastructural facilities, weak exchange rate, poor governance, corruption and general insecurity among others. The most disturbing in the country for now is menace of poverty and one of the factors that led to the sudden rise of poverty among people has been attributed to the lack of entrepreneurial skills, which can really create a sense of self-sufficiency. There is perhaps no better period than now, to understand and appreciate the relevance of entrepreneurship as the engine room of economic growth and development of nations worldwide (Okwu, 2012).This is necessary because, high rate of poverty is threat to Nigeria economic development nowadays.

\subsection{Objective of the Study}

To determine the extent in which entrepreneurship practices among small and medium -sized enterprises (SMEs) reduce poverty in Southwest Nigeria.

To evaluate the relationship between entrepreneurial practice and employment generation on SMEs in the Southwest Nigeria.

\subsection{Research Question}

To what extent does entrepreneurship practices among SMEs reduce poverty in Southwest Nigeria?

What is the relationship between entrepreneurial and employment generation among SMEs in Southwest Nigeria?

\subsection{Research Hypothesis}

Ho1: Entrepreneurial practices in SMEs have no significant improvement in standard of living in Southwest Nigeria.

Ho2: Entrepreneurial practices in SMEs have no significant improvement in employment generation in Southwest Nigeria. 


\subsection{Scope of the Study}

The scope of this study is focus on business owners of pure and table water industry in Osogbo and Ibadan, Osun and Oyo state respectively. The study focused on businesses operators in pure water industry in respective state. Osun and Oyo state are in Southwestern part of Nigeria.

\section{Literature Review}

Entrepreneurship Practices is the process, actions, activities behavior and sentiment employed by entrepreneurs who are showcase in their business dealings. (Ogundele 2012). Omisakin et al., 2016 and Ogundele 2017 explain that entrepreneurship practices has all activities employed by entrepreneurs in their business dealings. Anyakoha 2006, and Popoola M.A (2018) view Entrepreneurship Practices as business involves suitable people who take risk, identity business opportunities, acquire materials, plan, and implement actions that will achieve the business expectation. Also, Akeem O. A, Oluyemi and Popoola M. A. (2017) uphold this assertion.

Entrepreneurship Practices is an antidote to poverty reduction and job creation in an unstable economy and it requires the combined efforts of individuals and government. It also results in job creation and employment opportunities. Poverty is a common name in Nigeria despite various economic development policies designed to alleviate poverty through human capital development (Yahaya et al., 2011; Popoola M. A., 2014). In fact, Popoola (2018) in his argument explained that in all economic recession, as Nigeria is now, entrepreneurship practices among the youth will be a workable solution to poverty.

\subsection{Conceptual Framework}

According to the European Commission (2008), Entrepreneurship refers to an individual ability to turn ideas into action. It includes creativity, innovation and risk taking, as well as the ability to plan and manage projects in order to achieve objectives. Entrepreneurship is the process of designing, launching and running a new business. The concept of entrepreneurship is now very popular among people as a strategy of escaping poverty and creating enabling environment for socio-economic expansion and productivity. The focus on entrepreneurship development in this $21^{\text {st }}$ century is not just a theoretical approach but a development oriented action towards poverty reduction among rural and urban populace. Many developed nations have discovered the importance of small and medium scale enterprises to their economies and have not wasted time in investing into the sub-sector.

According to the Global Entrepreneurship Monitor (GEM) report in 2008, it is concluded that there is existing relationship between entrepreneurship and poverty reduction, which lead to economic development and poverty reduction among citizenry. It further explained that any government who want to improve the living standard of their people should imbibe the spirit culture of sound entrepreneurship.

\subsection{Theoretical Framework}

This study is conducted under the guiding light of poverty theory, which falls into one of the four perspectives as stated by Ogboru and Abiniku (2011). The four perspectives are:

The conservative, the Liberal Rerformists, the Radical Structural and the Social Exclusion. The Conservative theory namely; individualistic and culture of poverty positing that the poor are responsible for their poverty. It further explain that there is nothing we can do to move poor out of their present predicament. The Liberal Reformists' perspective, which deals with situational theory of poverty, is hinged on the fact that poverty results from experiences that individuals or group pass through. On their part, the radical Structural/Marxist perspective argued that capitalism produces poverty due to its exploitative syndrome. The social exclusion theory is predicated on poverty resulting from people who tend to be excluded from effective participation in society's activities due to segregation. Entrepreneurship practices tends to emphasize the identification and assessment of skills, understanding of entrepreneurial process, all needed for alleviating poverty through the creation of new business and assessing other business opportunities thereby making entrepreneurs create an employment opportunities and not seekers of employment opportunities.

\subsection{Empirical Framework}

Popoola M. A. (2018) conducted research on impact of entrepreneurship practices on poverty reduction, Osun state Nigeria evidence. Primary data is used in questionnaires. The study showed that there is a significant impact between entrepreneurship practices and poverty reduction.

Mulikat F.U and Sadiat I.A (2017) carried out research on effect of entrepreneurship on poverty reduction by using empirical fact from Sokoto State Nigeria. The use of primary data in terms of 300 questionnaire were 
administered. It comprises 233 entrepreneurs and 67 non-entrepreneur. The study showed that there is positive relationship between entrepreneurship and poverty reduction, that is, as the level of entrepreneurship rise, the rate of poverty reduced. The study advise that the government should provide funds, power and good transportation system as well entrepreneurship skill programme within its policy frame work in order to boost the level of entrepreneurship and reduce the level of poverty in the state. He further advised that government should intensify the high level of awareness of the benefit of entrepreneurship to the generality of its people but also provide enabling environment for entrepreneurial activities to function effectively.

The study also, emphasises his recommendation that the government in order to promote the level of entrepreneurship, should provide enough fund, power and good transportation system as well as entrepreneurship skill programme within its policy framework.

Ibitoye O., Atoyebi K. O., Sufian J. B. (2015) conducted research on Entrepreneurship and Poverty Reduction in Nigeria by way of empirical analysis, that is, the researcher adopted a stratified random sampling techniques, 500 entrepreneurs and apprenticeship were chosen from six recognize Local government of Lagos State. This result showed the positive relationship between entrepreneurship and poverty reduction.

I. Adofu and O. Akoji (2013) on their research study on alleviating poverty through the use of entrepreneurship skills acquisition in Kogi State Nigeria. Quantitative research was used. The result showed $65 \%$ of the respondent accepted that lack of entrepreneurship skills among youth especially in the rural areas is responsible for high rate of poverty in Nigeria. It further showed that entrepreneurship could reduce poverty rate by the use of quantitative research approach. The result featured that the high rate of poverty in Nigeria, which is rampant among the youth nowadays is caused by the inability to acquire entrepreneurship skill.

Ali Yassin \& Abdel (2013) take an insight on the relationship between entrepreneurship development and poverty reduction at Banadir region in Somalia. Their study indicated that there was weak positive correlation between entrepreneurship development \& poverty reduction. By way of analysis, sig or P-value was less enough suggesting that the two variables indicate that the computed R-value was -0.195 .

\section{Methodology}

The target population of the study was business owner in pure and table water industry in Osogbo and Ibadan metropolis. The study considered business owners of pure and table water industry in Osogbo and Ibadan township as the sampling frame from which 480 respondents were selected via enumeration and stratified sampling technique. The interview was specifically designed to accomplish the objective of the study.

The data is the collection of facts and figures relating to the population of study (Popoola 2014). The data used in this study is both primary and secondary sources. The primary data obtained through interview were collected directly from the respondent businesses. Secondary data were extracted mainly from most current publication of textbooks and related journal. These data are used to complement the data obtained in the field research through interview. In this study, data collection was done by direct interview, in-depth discussion with respondents, field notes and documentation.

Effective monitoring is done by observing the management of the work done by the respondent labor utilization, marketing and customer services. Descriptive analysis method used in this study. Descriptive statistical analysis techniques used include the value of the frequency distribution, the maximum and minimum value, the percentage value of each variable, the value of Average mean and Indicators Research. Also, PLS (Partial Least Square) is used to determined the effect of Entrepreneurship Practices on Poverty reduction.

\section{Results and Discussion}

Model testing was evaluated by looking at the value of the path, co efficient between variable influence of Independent variables (IV) Entrepreneurship Practices and dependent variable poverty reduction.

Based on PLS model outputs, model testing is done by looking at the path coefficient estimated value and the value of the critical point ( $\mathrm{t}$ - statistic) were significant at $\mathrm{a}=0.06$. The analysis result is shown below.

Table 1. Coefficient Independent Entrepreneurship Practices on Poverty Reduction

\begin{tabular}{|c|c|c|c|c|}
\hline $\begin{array}{c}\text { Effect between } \\
\text { variable }\end{array}$ & Path Coefficient & t -statistic & t- critical & Result \\
\hline EP(X) PR(Y) & 0.274 & 2.489 & 1.999 & Significant \\
\hline
\end{tabular}

Source: PLS Processed, 2018 
Description:

$\mathrm{E}=$ Entrepreneurship Practices

$\mathrm{PR}=$ Poverty Reduction

Whereas, Entrepreneurship practices is Independent Variable (X), Dependent variable is Poverty Reduction (Y). $\mathrm{X}=\mathrm{Y}$.

Based on Table 1 above, it can be seen that the entrepreneurship practices has positive and highly significant impact on poverty reduction in the Southwest Nigeria. This evidence by the $\mathrm{t}$ - test statistic $=2.489=\mathrm{t}-\mathrm{critical}$, namely 1.999 with path coefficient of 0.274 .

Based on this, empirical evidence shows that the implementation of independent entrepreneurship practices, which is run by pure, and table water businesses in Southwest Nigeria has been good, if observed dimension of attitudes to entrepreneurship practices, entrepreneurship motivation, entrepreneurial mindset and others entrepreneurial activities.

Descriptive results shows that many as $67.5 \%$ of respondents business do not have access to capital from financial institutions Bank. Also, $90 \%$ of respondents entrepreneurs have not ever had the opportunity to follow training. Improving the competence of entrepreneurial businesses through training in order to reduce poverty is very essential. Increase in income generation to entrepreneurs will help to reduce poverty among business operators and this will pave way for new employment opportunities for job seekers. Income generation can also obtained easily through proper entrepreneurship practices.

The results of this study found that Entrepreneurship Practices has great significant and positive effect on poverty reduction. The results support the research that has been done before by Popoola, M. A. (2018) in Osun state, Nigeria, Adofu I. and Akoji O. (2013) in Kogi state, Nigeria, Ali Yassin Ali (2013) in Somalia,Usman M. F. and Sadiat Ibn Adam (2017) in Sokoto state Nigeria and Abd Aziz Muttalib et al. (2016) in Indonesia.

\section{Conclusion and Recommendation}

Based on the results of this study and discussion, it can be shows that entrepreneurship practices among pure and table water business operators in Southwestern Nigeria is viable but still needs to be optimized entrepreneurial mindsets and competences in all their activities. Also, entrepreneurship practice has great significance on poverty reduction. It shows that poverty reduction can be done through raising the effectiveness of entrepreneurship practices.

Having carefully embarked on this study, it is recommended that entrepreneurs should be assist through the provision of soft loan by providing better access to capital through introduction of Federal small Business Administration to cater for young entrepreneurs. The main benefit of these loans is that, it will offer entrepreneurs the opportunity to receive financing on terms more favorable than they would otherwise receive in commercial banks. Also, government should formulate and introduce more entrepreneurship and vocational training center to boost the entrepreneurial skills among the people in order to play the developmental roles in economic development and this will reducing poverty among citizenry.

Government should try their best to compulsory entrepreneurship education in all institutions, from primary level up to university in order to imbibe the culture and skills of entrepreneurship among citizenry. By doing this, the unemployment among youth should reduce drastically, since they have been taught in the school to be self-employed through entrepreneurship practices.

\section{References}

1. Abd Aziz, Muttalib et al. (2016). The effect of entrepreneurship on poverty reduction proceedings of $82^{\text {nd }}$. The IIER International Conference, Banadaseri Bagawan, Brunci 15th-16 Decem ber, 2016.

2. Adofu, I., Akoji, O. (2013). Alleviating poverty through the use of entrepreneurship skill acquisition in Kogi State, Nigeria. International Open Journal of Economics, 1, 14-23.

3. Akeem, O. A., Oluyemi, A., and Popoola, M. A. (2017). Influence of Entrepreneurship practices on Small and Medium Enterprises Development (A case study of selected SMEs in Nigeria. International Journal of Management and Humanities (IJMH), 2(12), 2111-2119.

4. Ali Yassin, Shaeik Ali (2013). Entrepreneurship Development and Poverty Reduction. Empirical survey from Somalia. American International Journal of Social Sciences, 2(3), 108-113. 
5. Anyakoha, E. U. (2006). Practical tips for Economic Empowerment and Survival. Journal of Home Economic Research (JHER), 7(1), 9-17.

6. European Commission (2008). Entrepreneurship in higher education especially within non-business studies. Brussels: Final Report of Expert Group.

7. Ibitoye, Atoyebi \& Sufian J. B. (2015). Entrepreneurship and Poverty Reduction in Nigeria: An Empirical Analysis. Journal of Business and Management, 17, 16-19.

8. Muibi, O. O., Nakhid, C., and Frederick, R. (2016). Entrepreneurial orientation among migrants and small medium enterprises. Journal of Business Administration Research, 5(1), 9507-9515.

9. Ogboru, I., and Rose N. N. (2013). Official corruption and poverty reduction in Nigeria. International Journal of Art and Sciences, 5(1), 305-329.

10.Ogundele, O. J. K. (2007). Introduction of Entrepreneurship Development, Corporate Governance, and Small Business Management. Lagos "Molofin Nominees". A book of reading, pp. 559-595.

11.Ogundele, O. J. K, Waidi, A. A., and Hammed B. A. (2012). Entrepreneurship Training and Educational as Strategic Tool for Poverty Alleviation in Nigeria. American International Journal of Contemporary Research, 2(1), 148-156.

12.Ogundele, O. J. K. (2017).The Conceptual Clarifications of Entrepreneur. The Entrepreneur. A book of readings in honour of late Professor Sunday Oyewole Otokiti, 1-38.

13.Okwu, A. (2012). Business Environment and Small and Medium Enterprises (SMEs) Performance: Empirical Evidence from Lagos State, Nigeria. PhD thesis submitted to Babcock University.

14.Omoh, G. (2012). Is Nigeria in a poverty trap and population explosion? Vanguard newspaper, Monday $20^{\text {th }}$ February.

15.Popoola, M. A. (2014). Effect of Bank Consolidation on Lending Performance in Nigeria Banking System. Unpublished MSc thesis at National Open University of Nigeria.

16.Popoola, M. A. (2018). Impact of entrepreneurship practices on poverty reduction: evidence from Osun state Nigeria. International Journal of Advance Research and Innovative Ideas in Education, 4(3), 762-767.

17.Popoola, M. A. et al. (2018). Effect of Cultural Orientation on Entrepreneurial Cluster Initiatives in Kwara State Nigeria. International Journal of Advance Research and Innovative Ideas in Education (IJARIIE), 4(3), 768-777.

18.Popoola, M. A., Adewole, J. A., and Idih, O. E. (2018). Determinants of Deposit Money Banks Credit to Small and Medium Scale Enterprise Finance in Nigeria. International Journal of Advance Research and Innovative Ideas in Education (IJARIIE), 4(3), 1697-1710.

19.Usman, M. F., Sadiat ibn Adam (2017). The effect of entrepreneurship on poverty reduction: Evidence from Sokoto State, Nigreia. International Journal of Commerce and Management Research, 3(1), 94-100.

20.World Bank (2014). World Development Report: attacking poverty. NY: Oxford University Press.

21.Yahaya, K. A., Oseni, O. F., \& Abdulraheem, A. (2011). Effectiveness of Micro Finance Banks in Alleviating Poverty in Kwara State, Nigeria. Global Journal of Management and Business Research, March, 11(4), 12-21. 